\title{
Did common disjunct populations of freshwater fishes in northern Australia form from the same biogeographic events?
}

\author{
Benjamin D. Cook ${ }^{1,2,3,7}$, Peter J. Unmack ${ }^{4,5,8}$, Joel A. Huey ${ }^{1,6,9}$, and Jane M. Hughes ${ }^{1,2,6,10}$ \\ ${ }^{1}$ Australian Rivers Institute, Griffith University, Nathan, Queensland 4111, Australia \\ ${ }^{2}$ Tropical Rivers and Coastal Knowledge Commonwealth Environmental Research Facility, Griffith University, Nathan, \\ Queensland 4111, Australia \\ ${ }^{3}$ frc environmental, P.O. Box 2363, Wellington Point, Queensland 4160, Australia \\ ${ }^{4}$ National Evolutionary Synthesis Center, 2024 West Main Street, Suite A200, Durham, North Carolina 27705-4667 USA \\ ${ }^{5}$ Institute for Applied Ecology and Collaborative Research Network for Murray-Darling Basin Futures, University of Canberra, \\ Australia Capital Territory 2601, Australia \\ ${ }^{6}$ National Environmental Research Program Northern Australia Hub, Griffith University, Nathan, Queensland 4111, Australia
}

\begin{abstract}
Several freshwater fishes have disjunct (geographically discrete and widely spaced) distributions across northern Australia. We used mitochondrial deoxyribonucleic acid (mtDNA) data and phylogeographic analyses to examine the origin of these common disjunct distributions and to test the hypothesis that they were a result of a single biogeographic event. These disjunct distributions are not perfectly shared among species, but we selected 3 species that have wide ranges with the most similar disjunct geographic overlap: Spotted Blue Eye (Pseudomugil gertrudae), Pennyfish (Denariusa australis), and MacCulloch's Rainbow Fish (Melanotaenia maccullochi). Despite similarity in their present-day disjunct distributions, spatial genetic patterns varied considerably among the 3 species in terms of measures of molecular diversity, number of mtDNA lineages within each species, inter- and intra-regional spatial distribution of individual lineages within species, and degree of partitioning of genetic variation among regions. Pseudomugil gertrudae and $D$. australis each contained 1 to 2 divergent lineages at particular sites in 1 of the regions (Top End), but both species also contained lineages in this region that were more closely related to conspecific populations in other regions. Two regional populations (Top End and Northern Cape York Peninsula) of M. maccullochi consisted exclusively of highly divergent lineages that probably reflect cryptic species. When the divergent lineages within each species were excluded from temporal analyses, a single vicariant event among regions could not be rejected. Our results indicate that several regional populations are long-term relicts for M. maccullochi and that several sites within Top End are associated with localized long-term refugia for P. gertrudae and D. australis. A single biogeographic event in the mid- to late-Pleistocene may have created broadscale separation of most populations of these species.
\end{abstract}

Key words: phylogeography, lineage retention, endemism, introgression, simultaneous vicariance

Vicariance caused by past geological, climatic, or eustatic (sea-level change) processes is a key promoter of biological diversification and biogeographic patterning (e.g., Humphries and Parenti 1999, Avise 2000, 2004, Riginos 2005). Comparative phylogeographic analyses provide a means for examining the influence of past abiotic changes on species distributions and spatial partitioning of intraspecific genetic variation. Drastic or rapid landscape change should produce congruent phylogeographic patterns across multiple taxa indicative of a single vicariant event (e.g., Avise 2000, 2004,
Ponniah and Hughes 2004). However, protracted landscapechange processes may result in variation in the timing of the cessation of gene flow across a landscape among species. In such cases, variable phylogeographic patterns among codistributed taxa, indicative of multiple vicariant events, are expected.

Comparative phylogeographic studies often focus on species with broadly continuous distributions with significant overlap in their ranges (e.g., Soltis et al. 2006, Leaché et al. 2011). However, one interesting distribution pattern

E-mail addresses: ${ }^{7}$ bencook@frcenv.com.au; ${ }^{8}$ peter.mail2@unmack.net; ${ }^{9}$ j.huey@griffith.edu.au; ${ }^{10}$ jane.hughes@griffith.edu.au

DOI: 10.1086/674936. Received 02 March 2013; Accepted 04 September 2013; Published online 17 January 2014.

Freshwater Science. 2013. 33(1):263-272. @ 2014 by The Society for Freshwater Science. 
that is less frequently considered in comparative phylogeographic studies involves species, such as those restricted to mountain tops, that have common disjunct (discrete and widely spaced) distributions. These species are particularly interesting cases for assessing vicariance (e.g., Knowles and Carstens 2007, Shepard and Burbrink 2008) because their shared disjunct distributions suggest they have the same biogeographic history with identically timed geological events driving divergence. Numerous freshwater fishes have continuous distributions at the drainage-basin scale in northern Australia (e.g., Unmack 2001, Huey et al. 2014), but a number of species have disjunct distributions across this region (Unmack 2001, 2013).

Northern Australia underwent significant changes in aerial extent and climate during the Pleistocene. Glacial phases lowered sea levels, which led to repeated terrestrial and freshwater connections across the exposed continental shelf between Australia and New Guinea every 100-150,000 y (Hewitt 2000, Voris 2000). A concomitant increase in aridity that limited the spatial extent of hydrological connectivity and served to isolate populations complicated the potential for past connections among populations of freshwater biota during periods of low sea levels (Webster and Streten 1972, Unmack 2001, Cook et al. 2012). In previous phylogeographic studies of freshwater fauna in central northern Australia, investigators found primarily that divergence among the regional populations occurred in mid- to late-Pleistocene (reviewed by Cook et al. 2012, Unmack 2013). We examined a broader extent of northern Australia, but focused on 4 regions containing disjunct populations of 3 study species: Spotted Blue Eye, Pseudomugil gertrudae Weber 1911 (Pseudomugilidae); Pennyfish, Denariusa australis (Steindachner 1867) (Ambassidae); and MacCulloch's Rainbow Fish, Melanotaenia maccullochi Ogilby 1915 (Melanotaenidae). Cook and Hughes (2010) assessed the timing of divergence among regional populations of $D$. australis, and found that the midto late-Pleistocene was the likely time for the origin of the disjunct populations.

We used comparative phylogeographic analyses to examine the origin of common disjunct distributions in freshwater fishes in northern Australia and to test the hypothesis that their disjunct distributions were a result of a single biogeographic event. These disjunct distribution patterns are not always shared among species, but we selected 3 species that have wide ranges with similar disjunct geographic overlap for phylogeographic analyses (Fig. 1A-C). Our $1^{\text {st }}$ goal was to determine whether phylogeographic patterns are congruent among the 3 species. The $2^{\text {nd }}$ was to test the hypothesis that the disjunct populations were formed by a single vicariant event in the mid- to late-Pleistocene.

\section{METHODS}

\section{Study area}

The 4 regions representing the disjunct ranges of the 3 study species were Top End (TE), northwestern Cape

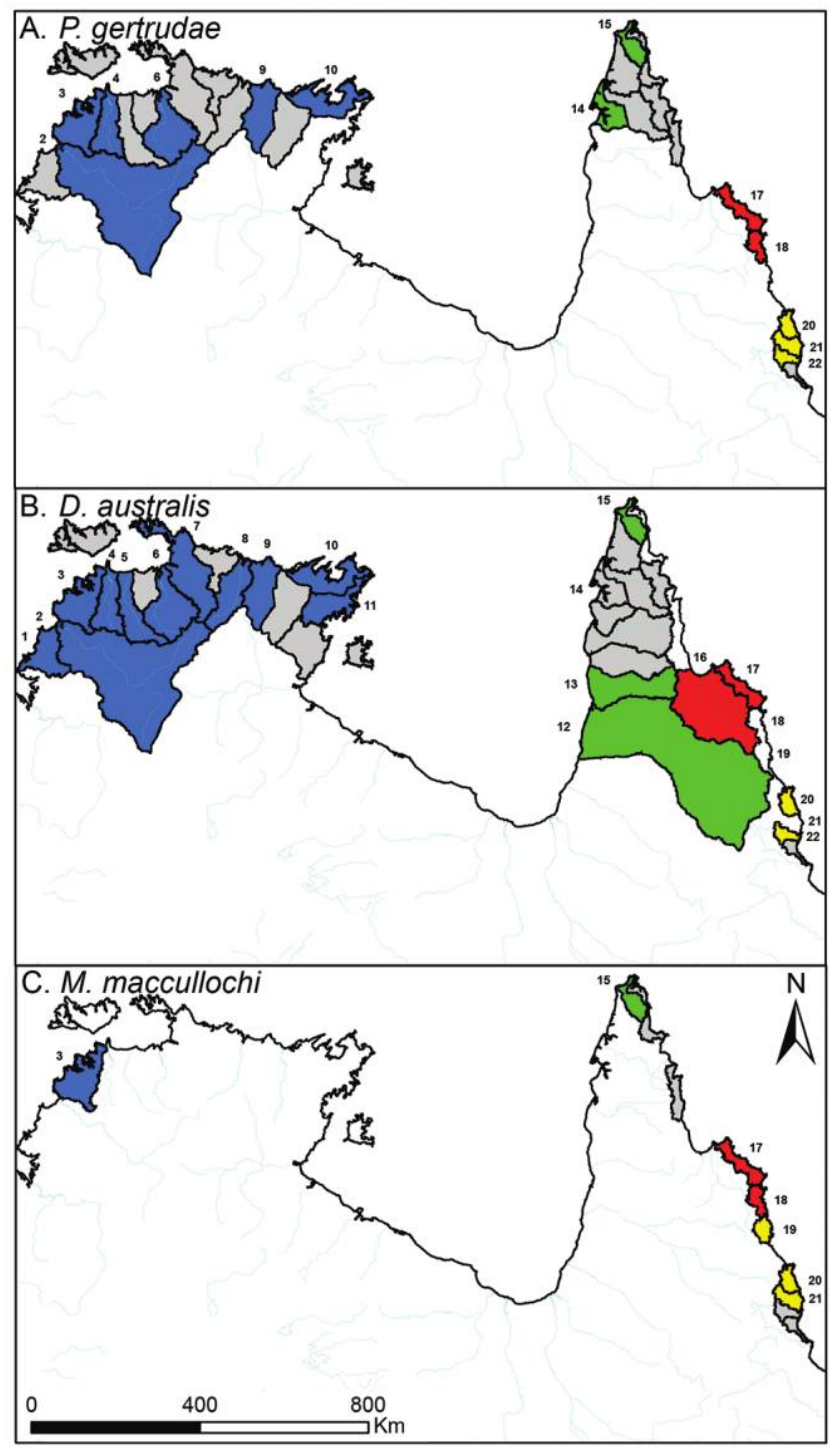

Figure 1. Map of northern Australia showing the drainage basins sampled for Pseudomugil gertrudae (A), Denariusa australis (B), and Melanotaenia maccullochi (C) across the 4 regions. All drainage basins (which are the same as in Table 1) are numbered in panel B, whereas only the basins sampled for the other 2 species are numbered in panels A and C. Colors indicate the drainage basins sampled from the 4 regions (blue $=$ Top End $[\mathrm{TE}]$, green $=$ northwestern Cape York Peninsula [NCYP], red = southeastern Cape York Peninsula $[\mathrm{SCYP}]$, yellow $=$ Wet Tropics $[\mathrm{WT}])$. Drainage basins that contain the species but were not sampled are shown in gray.

York Peninsula (NCYP), southeastern Cape York Peninsula (SCYP), and Wet Tropics (WT) (in order from west to east; Fig. 1A-C). TE is separated from NCYP by a wide arid region in the southern Gulf of Carpentaria that lacks much of the northern fish fauna and represents a different biogeographic subprovince (Unmack 2001, 2013). The NCYP and SCYP regions are separated by a major drainage divide and a narrow coastal region to the north of SCYP that lacks any larger rivers. SCYP and WT regions also 
are separated by a particularly narrow coastal region where the major drainage divide is quite close to the coastline and the area between these regions lacks any large rivers (Fig. 1A-C). This separation also is congruent with the boundary between the Eastern Speciose and North-Eastern subprovinces (Unmack 2001, 2013). These arid or narrow coastal regions are likely to limit movement between drainages, but the degree of isolation is difficult to quantify.

\section{Study species}

The 3 study species are typically lowland species occurring in a range of stream and wetland systems, including smaller coastal streams, lowland tributaries of large rivers, floodplain habitats, and dune lake systems. Their disjunct distributions extend from TE in the west to WT in the east (Fig. $1 \mathrm{~A}-\mathrm{C}$ ), and all 3 species are reported from southern New Guinea. Their regional patterns of disjunct distribution have substantial overlap at the continental scale, but their within-region patterns of distribution are variable, and often only 1 or 2 of the species were found at any 1 sampling locality. However, all 3 species were sampled at a few localities, including Ubgangee swamp in the Russel-Mulgrave drainage, the Jardine drainage, and several dune lakes at Cape Flattery. Many of the former wetland systems in the WT region have been drained and developed for urban and agricultural development, and all 3 species have undergone population declines in this region. Melanotaenia maccullochi is now extirpated from its type locality (Allen et al. 2002, Pusey et al. 2004).

Denariusa australis was previously called Denariusa bandata until the discovery of an older applicable name (Gon and Herzig-Straschil 1996). Data from previous work on this species, published as D. bandata (Cook and Hughes 2010) were included in our study, but we expanded geographic sampling in TE and SCYP. Melanotaenia maccullochi has been reported to contain divergent lineages among several of the disjunct regional populations (e.g., McGuigan et al. 2000, Unmack et al. 2013), and lineages from the WT and NCYP recently have been shown to be not monophyletic with respect to other species in the genus (Unmack et al. 2013). To date no investigator has considered phylogeographic patterns within M. maccullochi across all of its known regional populations. Therefore, we considered all regional populations of $M$. maccullochi in phylogeographic analyses, but we excluded the strongly divergent regional populations (i.e., NCYP and TE) from temporal analyses.

\section{Sampling and laboratory methods}

Specimens of each species were collected from $\geq 1$ river basins within each of the 4 regions (Table 1 ). Most mitochondrial deoxyribonucleic acid (mtDNA) data for D. australis are published (Cook and Hughes 2010; GenBank accession numbers GU474206-GU474370), but we added several previously unsampled populations in our study. Ge-
Table 1. Geographic origin and sample size of specimens used in our study. Sample-size information is formatted as number of individuals genotyped from drainage basin/number of sampling locations within drainage basin/number of haplotypes in drainage basin. Region codes are: TE = Top End, NCYP = northwestern Cape York Peninsula, SCYP = southeastern Cape York Peninsula, WT $=$ Wet Tropics. Drainage numbers are the same as in Fig. 1.

\begin{tabular}{|c|c|c|c|c|}
\hline Region & Drainage & $\begin{array}{c}P . \\
\text { gertrudae }\end{array}$ & $\begin{array}{c}D . \\
\text { australis }\end{array}$ & $\begin{array}{c}M . \\
\text { maccullochi }\end{array}$ \\
\hline $\mathrm{TE}$ & 1. Moyle & & $2 / 1 / 2$ & \\
\hline $\mathrm{TE}$ & 2. Daly & $14 / 1 / 2$ & $22 / 1 / 9$ & \\
\hline $\mathrm{TE}$ & 3. Finniss & $47 / 6 / 11$ & $12 / 2 / 2$ & $6 / 1 / 2$ \\
\hline $\mathrm{TE}$ & 4. Adelaide & $6 / 1 / 1$ & $21 / 1 / 6$ & \\
\hline $\mathrm{TE}$ & 5. Mary & & $6 / 1 / 2$ & \\
\hline & 6. South & & & \\
\hline $\mathrm{TE}$ & Alligator & $2 / 1 / 1$ & $13 / 1 / 7$ & \\
\hline $\mathrm{TE}$ & 7. East Alligator & & $8 / 2 / 8$ & \\
\hline $\mathrm{TE}$ & 8. Liverpool & & $9 / 1 / 2$ & \\
\hline $\mathrm{TE}$ & 9. Blythe & $11 / 1 / 2$ & $14 / 1 / 3$ & \\
\hline TE & 10. Buckingham & $2 / 1 / 2$ & $4 / 1 / 2$ & \\
\hline TE & 11. Koolatong & & $1 / 1 / 1$ & \\
\hline NCYP & 12. Mitchell & & $12 / 1 / 4$ & \\
\hline NCYP & 13. Coleman & & $10 / 1 / 1$ & \\
\hline NCYP & 14. Embley & $7 / 1 / 1$ & & \\
\hline NCYP & 15. Jardine & $14 / 2 / 3$ & $17 / 2 / 5$ & $21 / 4 / 7$ \\
\hline SCYP & 16. Normanby & & $3 / 1 / 1$ & \\
\hline SCYP & 17. Jeannie & $11 / 2 / 7$ & $2 / 1 / 1$ & $27 / 3 / 10$ \\
\hline SCYP & 18. Endeavour & $7 / 1 / 2$ & & $22 / 2 / 9$ \\
\hline WT & 19. Daintree & & & $6 / 1 / 1$ \\
\hline WT & 20. Mulgrave & $12 / 1 / 2$ & $9 / 1 / 2$ & $3 / 1 / 1$ \\
\hline WT & 21. Johnstone & $5 / 1 / 2$ & & $12 / 1 / 3$ \\
\hline WT & 22. Tully & $9 / 1 / 2$ & $11 / 1 / 3$ & \\
\hline
\end{tabular}

nomic DNA was extracted and a fragment of the ATPase 6 and $8 \mathrm{mtDNA}$ genes was amplified using the same primers, polymerase chain reaction (PCR) conditions, sequencing and aligning methods previously described (Cook and Hughes 2010). The total number of populations sampled and individuals genotyped for each species were: P. gertrudae: 19 and 147, D. australis: 21 and 176, and M. maccullochi: 13 and 97.

\section{Spatial genetic analyses}

To describe spatial patterns of genetic variation in each species, haplotype diversity $(h)$, nucleotide diversity $(\pi)$, and the number of segregating sites $(k)$ were calculated using Arlequin 3.5.1.2 (Excoffier and Lischer 2010) for each regional population (pooled samples from each region). The Fs statistic (Fu 1997) was calculated for each regional population for each species using DnaSP 5.0 (Librado and Rozas 2009). To test whether the empirical Fs 
values were significantly different from 0 , we compared them to simulated distributions of this statistic generated using 1000 coalescent model simulations in DnaSP that incorporated the observed number of segregating sites in the empirical data. Spatial genetic variation was assessed using Analysis of Molecular Variation (AMOVA; Excoffier et al. 1992) as implemented in Arlequin. Sampling sites were combined by river basin and defined as a population, which were then grouped into the 4 regions. The AMOVA analyses incorporated both the frequency and relative divergences of the haplotypes, giving hierarchical $\Phi$-indices, with statistical significance assessed using 10,000 permutations of the observed genotypes.

\section{Phylogenetic analyses}

The phylogenetic analyses included an appropriate closely related species as an outgroup as follows: Pseudomugil signifier Kner 1865, GenBank accession number JN016438; Ambassis agassizii Steindachner 1867, JN016232; Melanotaenia splendida (Peters 1866), JN016490, JN016501JN016503; and Melanotaenia ogilbyi (Weber 1910), JN016504. Maximum likelihood (ML) gene trees were built for each species using PhyML 2.4.4 (Guindon and Gascuel 2003) incorporating 1000 bootstrap replicates and input parameters for the model of sequence evolution as determined by MODELTEST 3.7 (Posada and Crandall 1998). Nodes with $<50 \%$ bootstrap support were collapsed using MESQUITE version 2.72 (Maddison and Maddison 2000). Lineages were defined by deeper nodes in the trees with bootstrap $>50 \%$.

\section{Temporal analyses}

We used the coalescent time estimating approach as implemented in MDIV (Nielsen and Wakeley 2001) to estimate the timing of divergence within each species. We did this analysis with the following lineages for each species: lineages PG-A and PG-B for P. gertrudae; lineage DA-A for $D$. australis; and lineage MM-A for M. maccullochi. We made pairwise population comparisons only between populations that were the closest to each other in the fol- lowing sequence along the coastline (TE vs NCYP, NCYP vs SCYP, SCYP vs WT). Alternative combinations of regional populations were not assessed because the study species are lowland species distributed in coastal areas within drainage basins (Pusey et al. 2004). Thus, past inland connectivity across upland catchment divides is extremely unlikely.

Coalescent parameters were estimated using the finite sites model of nucleotide evolution (Hasegawa Kishino Yano [HKY]; Hasegawa et al. 1985) and 5,000,000 Markov chain iterations with a $10 \%$ burn-in. We set $\mathrm{M}_{\mathrm{MAX}}$ (maximum value for the scaled migration rate) to 0 and $\mathrm{T}_{\mathrm{MAX}}$ (maximum value for the scaled divergence time) to 10 . Three replicate runs with a different starting seed number were conducted for each pairwise comparison. For each of the 9 pairwise population comparisons across the 3 species, the highest likelihood value for the parameter $T$ (divergence time in mutational time) and the mutation parameter $\theta(\theta=2 \mathrm{Ne} \mu$, where $\mathrm{Ne}$ is the effective female population size and $\mu$ is the substitution rate/nucleotide) were converted to time in years $(\mathrm{t})$ using the formula, $\mathrm{t}=T(\theta / 2 \mu)$. The per lineage sequence divergence rate used to calculate $\mu$ was $1.3 \%$ per million years, which is the best available divergence rate of the mtDNA ATPase6/8 genes estimated from various species of tropical freshwater fishes across several orders (Bermingham et al. 1997). For each test, we calculated the $95 \%$ confidence bounds for values of $T$ that were distributed within the curve, and converted these bounds to time using the above-mentioned formula. If the timing estimates overlapped we could not reject a single vicariant event.

\section{RESULTS}

\section{Spatial genetic analyses}

Each species had between 30-58 haplotypes (Table 2). In all species, no haplotypes were shared among rivers within regions or between regions. Molecular diversity was highest in TE for P. gertrudae and D. australis, and highest in NCYP and SCYP for M. maccullochi (Table 3). All regional populations for all species had nonsignificant values

Table 2. The number of base pairs, GenBank accession number, unique haplotypes, and sequence-evolution model details for the 3 study species. AIC = Akaike's Information Criterion, PINVAR = proportion of invariable sites, $\operatorname{TrN}=$ Tamura Nei, $\mathrm{I}=$ invariant, $\mathrm{G}=$ gamma, Alpha $=$ gamma distribution of rate variation among base pairs.

\begin{tabular}{lcccccc}
\hline \multicolumn{1}{c}{ Species } & $\begin{array}{c}\text { No. base pairs } \\
\text { of fragment }\end{array}$ & $\begin{array}{c}\text { GenBank accession } \\
\text { number }\end{array}$ & $\begin{array}{c}\text { No. unique } \\
\text { haplotypes }\end{array}$ & $\begin{array}{c}\text { Best model } \\
\text { based on AIC }\end{array}$ & PINVAR & Alpha \\
\hline Pseudomugil gertrudae & 658 & JN016439-JN016469 & 31 & $\operatorname{TrN}+$ I & 0.607 & - \\
Denariusa australis & 694 & JN016233-JN016249 & 58 & TrN + G & - & 0.205 \\
Melanotaenia maccullochi & 573 & JN016470-JN016489; & 30 & TrN + I + G & 0.574 & 0.921 \\
& & JN016491-JN016500 & & & \\
\hline
\end{tabular}


Table 3. Molecular diversity within each regional population of Pseudomugil gertrudae, Denariusa australis, and Melanotaenia maccullochi. $h=$ haplotype diversity, $\pi=$ nucleotide diversity, $k( \pm \mathrm{SE})=$ number of segregating sites, $F \mathrm{~s}=$ Fu's (1997) Fs statistic, with $p$-values in parentheses. Bold indicates values that are significantly different from 0 .

\begin{tabular}{lccrr}
\hline \multicolumn{1}{c}{ Region } & $h$ & $\pi$ & $k$ & $F s$ \\
\hline P. gertrudae & & & & $3.509 \pm 1.806$ \\
TE & $0.915 \pm 0.012$ & $0.006 \pm 0.004$ & $0.771 \pm 0.587$ & $-0.499(0.259)$ \\
NCYP & $0.642 \pm 0.054$ & $0.001 \pm 0.001$ & $2.052 \pm 1.206$ & $0.031(0.767)$ \\
SCYP & $0.863 \pm 0.061$ & $0.004 \pm 0.002$ & $1.283 \pm 0.832$ & $0.020(0.246)$ \\
WT & $0.723 \pm 0.055$ & $0.002 \pm 0.002$ & & $0.020(0.491)$ \\
D. australis & & & $11.313 \pm 5.172$ & $-0.824(0.085)$ \\
TE & $0.950 \pm 0.009$ & $0.012 \pm 0.008$ & $2.289 \pm 1.283$ & $-0.204(0.219)$ \\
NCYP & $0.866 \pm 0.027$ & $0.003 \pm 0.002$ & $3.000 \pm 1.874$ & $0.363(0.714)$ \\
SCYP & $0.800 \pm 0.164$ & $0.004 \pm 0.003$ & $2.663 \pm 1.481$ & $-0.044(0.815)$ \\
WT & $0.695 \pm 0.070$ & $0.004 \pm 0.002$ & & \\
M. maccullochi & & & $0.667 \pm 0.587$ & $0.192(0.640)$ \\
TE & $0.333 \pm 0.215$ & $0.001 \pm 0.001$ & $3.371 \pm 1.800$ & $-0.082(0.580)$ \\
NCYP & $0.743 \pm 0.083$ & $0.006 \pm 0.004$ & $2.854 \pm 1.529$ & $-\mathbf{0 . 4 2 4}(\mathbf{0 . 0 2 4})$ \\
SCYP & $0.912 \pm 0.018$ & $0.005 \pm 0.003$ & $0.400 \pm 0.392$ & $0.167(0.575)$ \\
WT & $0.257 \pm 0.141$ & $0.001 \pm 0.001$ & & \\
\hline
\end{tabular}

for Fu's Fs, with the exception of SCYP for M. maccullochi (Table 3). AMOVA indicated very strong population genetic subdivision in all species at all levels of the hierarchy, with the exception of $D$. australis at the largest spatial scale (Table 4).

The models of nucleotide evolution selected by MODELTEST for each species are presented in Table 2. The topology of the gene trees varied among the 3 species in terms of the number of lineages, the spatial distribution of each lineage within and among the regions, and the amount of genetic divergence among the lineages.

Pseudomugil gertrudae had 3 lineages, with the mostdivergent lineage in this species (lineage PG-C) restricted to Leichhardt Springs within TE (upper South Alligator drainage, river 6). The distribution of the other lineages in P. gertrudae (lineages PG-A and PG-B) separated the 2 northwestern regions (TE and NCYP) from the 2 southeastern regions (SCYP and WT) (Fig. 2). Lineage PG-A also suggested a minor subdivision within TE between western (rivers 2-5) and eastern (rivers 6-11) drainages, except that the Daly drainage (river 2) grouped with the eastern populations.

As reported by Cook and Hughes (2010), Denariusa australis had only 2 lineages, which were only slightly divergent (2\%), with the principal lineage (Lineage DA-A) distributed across all 4 regions, and Lineage DA-B geographically restricted to the western side of TE. Lineage DA-B was absent from the Daly drainage (river 2), with haplotypes from the Daly drainage forming a slightly divergent group within DA-A (haplotypes DA-19 to DA-27; Fig. 3).

The gene tree for M. maccullochi had 4 major mtDNA lineages, 2 of which (MM-B and MM-C) were restricted to NCYP and TE, respectively. Lineage MM-A was distributed across SCYP and WT, and the $4^{\text {th }}$ lineage was from the Daintree drainage (river 19) in WT and was closely related to the outgroup taxon M. splendida (Fig. 4).

Table 4. Results of analysis of molecular variance (AMOVA). $p$-values for the $\Phi$-indices are shown in parentheses with statistically significant results shown in bold.

\begin{tabular}{lccc}
\hline \multirow{2}{*}{ Comparison } & \multicolumn{1}{c}{$\Phi$-indices } \\
\cline { 2 - 4 } & P. gertrudae & D. australis & M. maccullochi \\
\hline Among regions $\left(\Phi_{\mathrm{CT}}\right)$ & $\mathbf{0 . 5 7 9}(<\mathbf{0 . 0 0 1})$ & $0.143(0.099)$ & $\mathbf{0 . 8 0 1}(\mathbf{0 . 0 1 4})$ \\
Among populations within regions $\left(\Phi_{\mathrm{SC}}\right)$ & $\mathbf{0 . 5 6 1}(<\mathbf{0 . 0 0 1})$ & $\mathbf{0 . 7 9 7}(<\mathbf{0 . 0 0 1 )}$ & $\mathbf{0 . 1 5 9}(<\mathbf{0 . 0 0 1})$ \\
Among all populations $\left(\Phi_{\mathrm{ST}}\right)$ & $\mathbf{0 . 8 1 5}(<\mathbf{0 . 0 0 1})$ & $\mathbf{0 . 8 2 6}(<\mathbf{0 . 0 0 1 )}$ & $\mathbf{0 . 8 3 3}(<\mathbf{0 . 0 0 1 )}$ \\
\hline
\end{tabular}




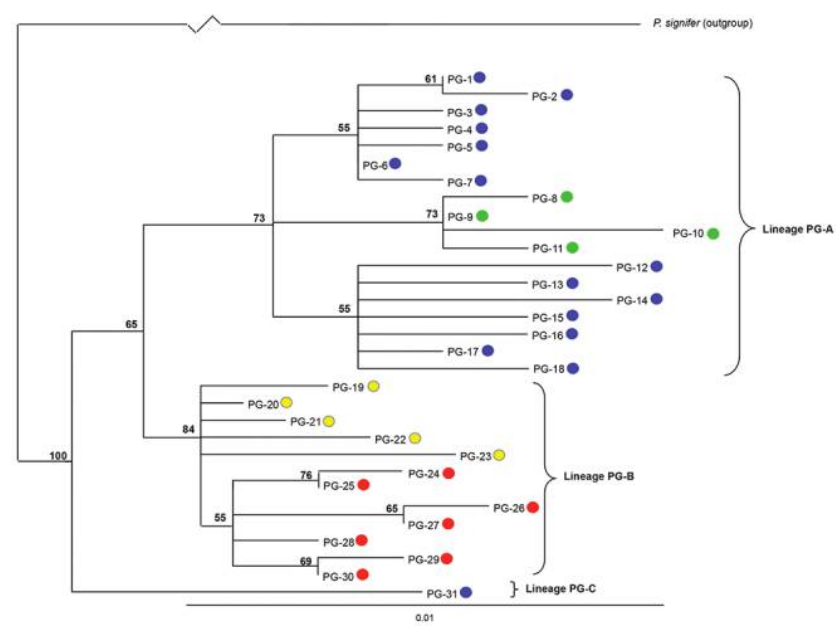

Figure 2. Maximum likelihood ATPase6/8 mtDNA gene tree for Pseudomugil gertrudae (loglk $=-1089.509)$. Colored dots indicate the region of origin for each haplotype (see Fig. 1 for color codes).

\section{Temporal genetic analyses}

The MDIV analyses indicated that the timing of coalescence among the regional populations within each species overlapped and ranged from 0.25 to 2.5 million y ago (mya) (Fig. 5). Similarly, temporal analyses indicated overlapping estimates for divergences within each species among all regions.

\section{DISCUSSION}

Spatial congruence of molecular biogeographic patterns

Despite the relative commonality of their disjunct distributions, spatial genetic patterns varied considerably among P. gertrudae, D. australis, and M. maccullochi. Variation in phylogeographic patterns was evident in measures of molecular diversity, the number of lineages within each species, the spatial distribution of individual lineages within species both within and among regions, and the degree of partitioning of genetic variation among regions. Other studies of codistributed freshwater fishes with continuous distributions across either southeastern or northern Australia, including a number of congeneric species, also have shown strikingly different levels of phylogeographic structure (Thacker et al. 2007, 2008, Huey et al. 2014). This result indicates that phylogenetic proximity, commonality of distribution, and ecological traits are not necessarily good predictors of shared phylogeographic history. Phylogenetic analysis has

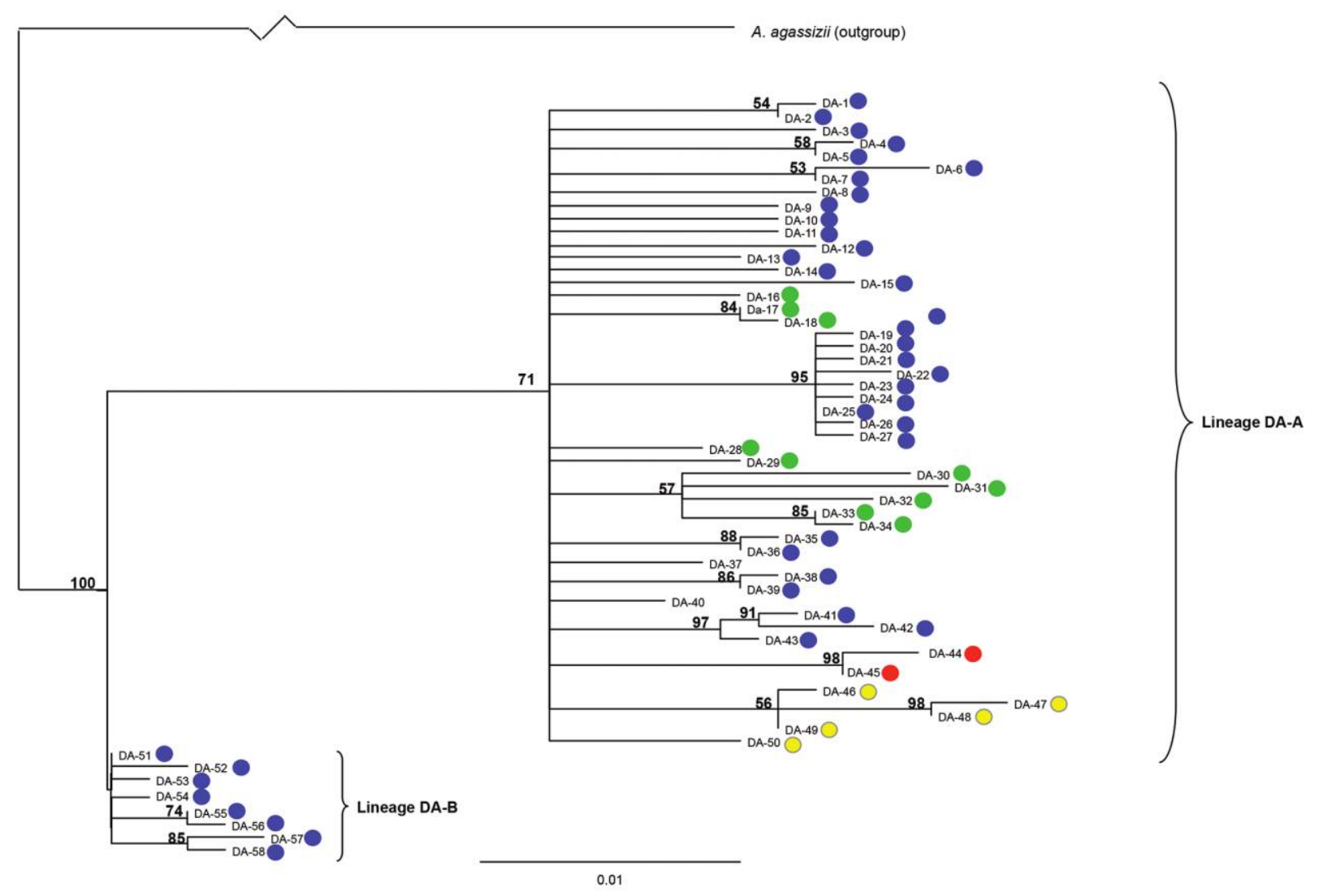

Figure 3. Maximum likelihood ATPase6/8 mtDNA gene tree for Denariusa australis (loglk $=-1721.124)$. Colored dots indicate the region of origin for each haplotype (see Fig. 1 for color codes). 


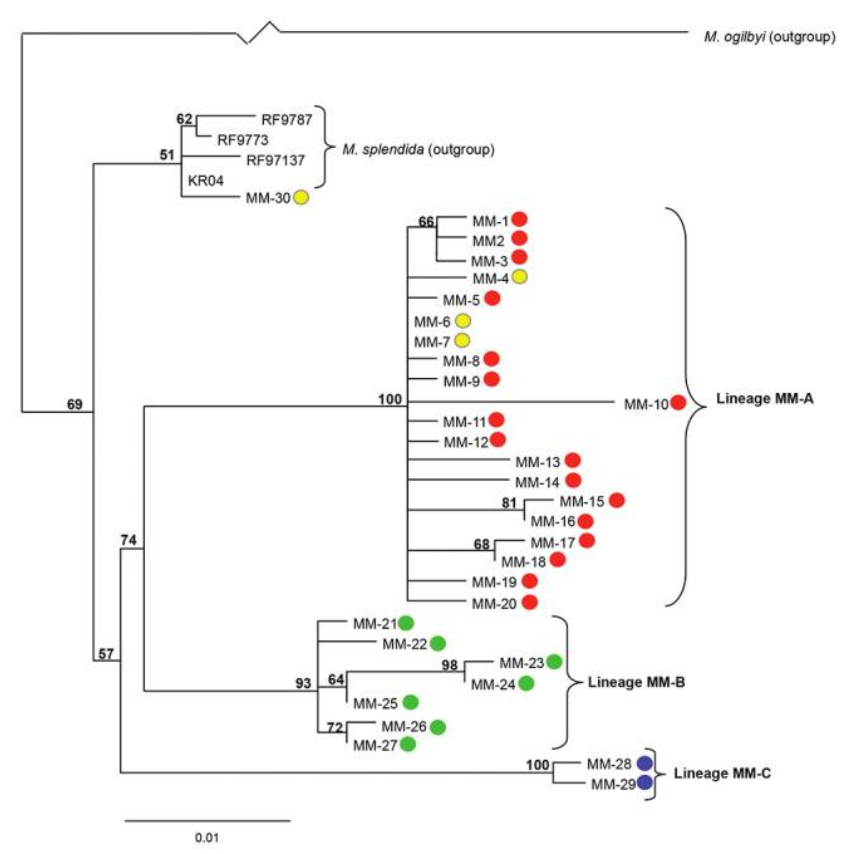

Figure 4. Maximum likelihood ATPase6/8 mtDNA gene tree for Melanotaenia maccullochi (loglk $=-1340.586)$. Colored dots indicate the region of origin for each haplotype (see Fig. 1 for color codes).

shown strong (species level) genetic subdivision among disjunct populations of the freshwater fish Craterocephalus stramineus in northern Australia (Unmack and Dowling 2010), but our study indicates that strong divergence among disjunct populations is not always observed. Indeed, in some cases (e.g., P. gertrudae and D. australis), stronger phylogeographic structure may occur within putatively contiguous regional population units. Our 3 study species have strikingly different phylogeographic patterns, but given the lack of shared haplotypes and levels of genetic divergence, no evidence exists for on-going gene flow among drainages or among regions in any species. Furthermore, most have nonsignificant $F$ s values, suggesting that they have formed demographically stable populations. Several other freshwater fishes and decapod crustaceans with continuous distributions in northern Australia also have formed demographically stable and genetically differentiated lineages despite molecular evidence for widespread gene flow in some species in the recent past across the Carpentaria region (de Bruyn et al. 2004, Baker et al. 2008, Masci et al. 2008, Huey et al. 2010, Cook et al. 2012).

Denariusa australis showed limited phylogeographic structure among regions, but $P$. gertrudae and $M$. maccullochi each showed significant phylogeographic subdivision among some of the regions, with $P$. gertrudae also having shallower phylogeographic subdivision among regions within lineages PG-A and PG-B (Figs 2, 4). Striking morphological variation (i.e., length of $1^{\text {st }}$ dorsal and pelvic fin filaments; and height, shape, and patterns of spots on $2^{\text {nd }}$ dorsal and anal fins) is reported within P. gertrudae, even among populations within regions (Allen et al. 2002). Molecular data are congruent with the morphological data in indicating strong heterogeneity within this species, even at within-region scales. Melanotaenia maccullochi also contains several geographically differentiated color forms (Allen et al. 2002), with variation reported in the intensity of body stripes and in the markings on dorsal and anal fins among several of the regional populations. A recent study has shown that M. maccullochi from WT and NCYP are not monophyletic relative to other species in the "Maccullochi" group sampled from southern New Guinea (Unmack et al. 2013). The molecular data we presented for this species shows higher differentiation among the lineages than that for P. gertrudae, indicating that morphological variation among the regional populations of M. maccullochi may reflect interspecific variation, although more detailed analyses of morphological and genetic data are needed (see Page et al. 2005).

Phylogeographic structuring was lowest between SCYP and WT in all species, but haplotypes were not shared among the regions for any of the species. Both SCYP and WT contain coastal plains with extensive wetland systems, and SCYP also contains diverse dune-lake wetland systems. The continental shelf in the vicinity of these 2 regions is relatively wide (Unmack 2001), and it is possible that during recent periods of lowered sea levels these wetland systems could have been more extensive and continuous between these 2 regions over exposed sections of the continental shelf. Furthermore, the degree of geographic separation between the SCYP and WT regions is notably less than that among the other regions, and from a biogeographic perspective, our molecular data indicate no biogeographic subdivision between the SCYP and the WT regions.

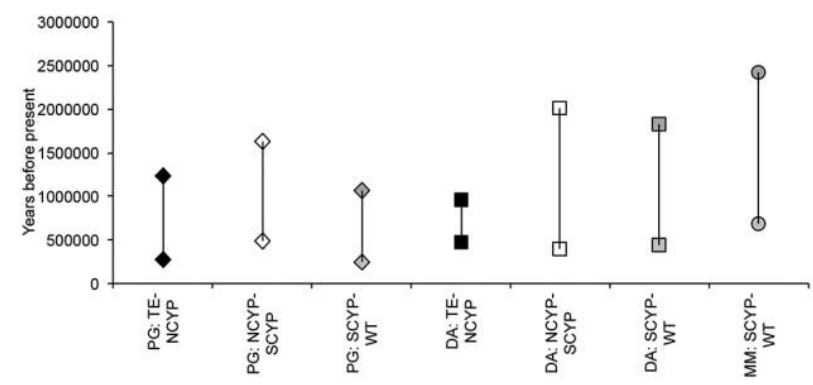

Figure 5. Results of MDIV analyses, showing the estimated timing of coalescence in years between pairs of regional populations. $\mathrm{PG}=$ Pseudomugil gertrudae, $\mathrm{DA}=$ Denariusa australis, $\mathrm{MM}=$ Melanotaenia maccullochi, $\mathrm{TE}=$ Top End region, $\mathrm{NCYP}=$ northwestern Cape York Peninsula region, SCYP = southeastern Cape York Peninsula region, WT $=$ Wet Tropics region. 
Both $P$. gertrudae and $D$. australis show a shallow (i.e., within lineage) east vs west phylogeographic subdivision within TE in the vicinity of rivers 4 and 5 (Fig. 1A, B). The Daly drainage (river 2), which is almost the most-western drainage in TE, grouped with populations on the eastern side of TE for both $P$. gertrudae and $D$. australis, which in the case of $D$. australis, represents the most divergent group of haplotypes within lineage DA-A (Fig. 3). The retention of divergent lineages within the Daly drainage has been reported for several other fishes, including Oxyeleotris selheimi (Macleay 1884) (Eleotridae), Neosilurus pseudospinosus Allen and Feinberg 1998 (Plotosidae) (Huey et al. 2014), and Mogurnda mogurnda (Richardson 1844) (Eleotridae) (Cook et al. 2011), indicating that this drainage probably has been a long-term refugium for various freshwater fishes and has subsequently been colonized by divergent populations from elsewhere in the TE region (see Cook et al. 2011). Therefore, the Daly drainage appears to have high phylogenetic diversity and phylogenetic endemism across a number of unrelated freshwater fish species, and is reported to have high species richness and taxonomic endemism for freshwater fishes and freshwater turtles (Hermoso et al. 2011). Pseudomugil gertrudae also contains a very divergent, though intraspecific, lineage that is restricted to Leichhardt Springs at the base of the Arnhem Plateau ( $\sim 38 \mathrm{~m}$ asl) in the upper South Alligator drainage (river 6). Leichhardt Springs contains other endemic freshwater taxa (e.g., a taxon within the isopod genus Eophreatoicus; Wilson et al. 2009; and a probable cryptic species of rainbowfish related to $M$. trifasciata; Unmack et al. 2013), suggesting that it probably has high conservation value. TE overall contains refugial populations for $P$. gertrudae and D. australis, and our results show the existence of several geographically localized refugia within this region, 'refugia within refugia' (sensu Cooper et al. 2011), with these places also having high endemism for other freshwater biota.

Last, M. maccullochi from the Daintree drainage (river 19) in WT contains haplotypes that are closely related to haplotypes from the outgroup species M. splendida sampled across WT (Fig. 4). Past introgression among rainbowfishes is common (Unmack et al. 2013), but our study is the $1^{\text {st }}$ record of $M$. maccullochi containing mtDNA from another species.

\section{Temporal concordance of biogeography history}

The ranges of estimates for the timing of vicariance indicated by the MDIV analyses were broad and overlapped, suggesting that a single vicariant event in the past could not be rejected among the species for any of the regions (M. maccullochi from TE and NCYP was excluded from these analyses). The MDIV estimates for divergence time coincided with the mid- to late-Pleistocene (Fig. 5), but none overlapped with the last glacial maximum (LGM), a result previously found for $D$. australis (Cook and Hughes 2010) and several other freshwater species in the region (see Cook et al. 2012). Climatic and landscape changes associated with Pleistocene glacial cycles are thought to have played key roles in facilitating widespread connectivity and gene flow within a range of freshwater species in northern Australia (see Cook et al. 2012). These same historical biogeographic processes also appear to have facilitated strong vicariance among a number of codistributed fishes, highlighting the important role of landscape evolution on biogeographic patterning in northern Australia (see Bowman et al. 2010).

\section{ACKNOWLEDGEMENTS}

The Tropical Rivers and Coastal Knowledge Commonwealth Environmental Research Facility (TRaCK) receives major funding for its research through the Australian Government's Commonwealth Environment Research Facilities initiative, the Australian Government's Raising National Water Standards Program, Land and Water Australia, the Fisheries Research and Development Corporation, and the Queensland Government's Smart State Innovation Fund. We also acknowledge the Australian Government Department of Sustainability, Environment, Water, Population and Communities, the National Environmental Research Program Northern Australia Hub, and the Australian Rivers Institute, Griffith University, for funding our study. We thank Tim Page, Kate Masci, James Fawcett, and Jodie Haig for helping with field sampling and Brad Pusey, Colton Perna, Mark Adams, Dave Wilson, Duncan Buckle, Chris Humphry, Paul Godfrey, Paul Thuesen, Tim Page, and Damien Burrows for providing samples. Mark Kennard and Paul Thuesen each independently confirmed our morphological identification of the specimens from the Daintree River as M. maccullochi.

\section{LITERATURE CITED}

Allen, G. R., S. H. Midgley, and M. Allen. 2002. Field guide to the freshwater fishes of Australia. Western Australian Museum, Perth, Australia.

Avise, J. C. 2000. Phylogeography: the history and formation of species. Harvard University Press, Cambridge, Massachusetts.

Avise, J. C. 2004. Molecular markers, natural history and evolution. $2^{\text {nd }}$ edition. Sinauer, Sunderland, Massachusetts.

Baker, N., M. de Bruyn, and P. B. Mather. 2008. Patterns of molecular diversity in wild stocks of the redclaw crayfish (Cherax quadricarinatus) from northern Australia and Papua New Guinea: impacts of Plio-Pleistocene landscape evolution. Freshwater Biology 53:1592-1605.

Bermingham, E., S. McCafferty, and A. Martin. 1997. Fish biogeography and molecular clocks: perspectives from the Panamanian Isthmus. Pages 113-118 in T. Kocher, and C. Stepien. Molecular systematics of fishes. Academic Press, New York.

Bowman, D., G. Brown, M. Braby, L. Cook, M. Crisp, F. Ford, S. Haberle, J. Hughes, and Y. Isagi. 2010. Biogeography of

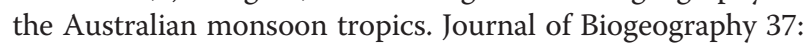
201-216. 
Cook, B. D., M. Adams, P. B. Mather, and J. M. Hughes. 2012. Statistical phylogeographic tests of competing 'Lake Carpentaria Hypotheses' in the mouth-brooding freshwater fish, Glossamia aprion (Apogonidae). Marine and Freshwater Research 63:450-456.

Cook, B. D., and J. M. Hughes. 2010. Historical population connectivity and fragmentation in a freshwater fish with a disjunct distribution (pennyfish, Denariusa bandata). Journal of the North American Benthological Societv 29:1119-1131.

Cook, B. D., M. J. Kennard, K. Real, B. Pusey, and J. M. Hughes. 2011. Landscape genetic analysis of the tropical freshwater fish Mogurnda mogurnda (Eleotridae) in a monsoonal river basin: importance of hydrographic factors and population history. Freshwater Biology 56:812-827.

Cooper, S. J., M. S. Harvey, K. M. Saint, and B. Y. Main. 2011. Deep phylogeographic structuring of populations of the trapdoor spider Moggridgea tingle (Migidae) from southwestern Australia: evidence for long-term refugia within refugia. Molecular Ecology 20:3219-3236.

de Bruyn, M., C. J. Wilson, and P. B. Mather. 2004. Reconciling geography and genealogy: phylogeography of giant freshwater prawns from the Lake Carpentaria region. Molecular Ecology 13:3515-3526.

Excoffier, L., and H. E. L. Lischer. 2010. Arlequin suite ver 3.5: a new series of programs to perform population genetics analyses under Linux and Windows. Molecular Ecology Resources 10:564-567.

Excoffier, L., P. E. Smouse, and J. M. Quattro. 1992. Analysis of molecular variance inferred from metric distances among DNA haplotypes: application to human mitochondrial DNA restriction data. Genetics 131:479-491.

Fu, Y. X. 1997. Statistical tests of neutrality of mutations against population growth, hitchhiking and background selection. Genetics 147:915-925.

Gon, O., and B. Herzig-Straschil. 1996. Taxonomic status of Steindachner's Apogon australis and Apogonichthys gillii (Teleostei, Apogonidae). Copeia 1996:1029-1031.

Guindon, S., and O. Gascuel. 2003. A simple, fast, and accurate algorithm to estimate large phylogenies by maximum likelihood. Systematic Biology 52:696-704.

Hasegawa, M., H. Kishino, and T. Yano. 1985. Dating of humanape splitting by a molecular clock of mitochondrial DNA. Journal of Molecular Evolution 22:160-174.

Hermoso, V., M. Kennard, B. Pusey, and M. Douglas. 2011. Identifying priority areas for the conservation of freshwater biodiversity in northern Australia. Pages 133-150 in B. J. Pusey (editor). Aquatic biodiversity in northern Australia: patterns, threats and future. Charles Darwin University Press, Darwin, Australia.

Hewitt, G. 2000. The genetic legacy of the Quaternary ice ages. Nature 405:907-912.

Huey, J. A., A. M. Baker, and J. M. Hughes. 2010. High levels of genetic structure in the Australian freshwater fish, Ambassis macleayi. Journal of the North American Benthological Society 29:1148-1160.

Huey, J. A., B. D. Cook, P. J. Unmack, and J. M. Hughes. 2014. Broadscale phylogeographic structure of five freshwater fishes across the Australian Monsoonal Tropics. Freshwater Science 33:273-287.
Humphries, C. J., and L. R. Parenti. 1999. Cladistic biogeography: interpreting patterns of plant and animal distributions. $2^{\text {nd }}$ edition. Oxford University Press, New York.

Knowles, L. L., and B. C. Carstens. 2007. Estimating a geographically explicit model of population divergence. Evolution 61:477-493.

Leaché, A. D., S. C. Crews, and M. J. Hickerson. 2011. Two waves of diversification in mammals and reptiles of Baja California revealed by hierarchical Bayesian analysis. Biology Letters 3:646-650.

Librado, P., and J. Rozas. 2009. DnaSP v5: a software for comprehensive analysis of DNA polymorphism data. Bioinformatics 25:1451-1452.

Maddison, W. P., and D. R. Maddison. 2000. MESQUITE: a modular system for evolutionary analysis. Version 2.72. (Available from: http://mesquiteproject.org/mesquite/mesquite.html)

Masci, K. D., M. Ponniah, and J. M. Hughes. 2008. Patterns of connectivity between the Lake Eyre and Gulf drainages, Australia: a phylogeographic approach. Marine and Freshwater Research 59:751-760.

McGuigan, K., D. Zhu, G. R. Allen, and C. Moritz. 2000. Phylogenetic relationships and historical biogeography of melanotaeniid fishes in Australia and New Guinea. Marine and Freshwater Research 51:713-723.

Nielsen, R., and J. Wakeley. 2001. Distinguishing migration from isolation: a Markov chain Monte Carlo approach. Genetics 158:885-896.

Page, T. J., S. C. Choy, and J. M. Hughes. 2005. The taxonomic feedback loop: symbiosis of morphology and molecules. Biology Letters 1:39-42.

Ponniah, M., and J. M. Hughes. 2004. The evolution of Queensland spiny mountain crayfish of the genus Euastacus. I. Testing vicariance and dispersal with interspecific mitochondrial DNA. Evolution 58:1073-1085.

Posada, D., and K. A. Crandall. 1998. MODELTEST: testing the model of DNA substitution. Bioinformatics 14:817-818.

Pusey, B., M. Kennard, and A. Arthington. 2004. Freshwater fishes of north-eastern Australia. CSIRO Publishing, Canberra, Australia.

Riginos, C. 2005. Cryptic vicariance in Gulf of California fishes parallels vicariant patterns found in Baja, California mammals and reptiles. Evolution 59:2678-2690.

Shepard, D. B., and F. T. Burbrink. 2008. Lineage diversification and historical demography of a Sky Island salamander, Plethodon ouachitae, from the Interior Highlands. Molecular Ecology 17: 5315-5335.

Soltis, D. E., A. B. Morris, J. S. McLachlan, P. S. Manos, and P. S. Soltis. 2006. Comparative phylogeography of unglaciated North America. Molecular Ecology 15:4261-4293.

Thacker, C., P. J. Unmack, L. Matsui, P. Duong, and E. Huang. 2008. Phylogeography of Philypnodon species (Teleostei: Perciformes: Gobioidei: Eleotridae) across eastern Australia: comparative evolution of a sister pair. Biological Journal of the Linnean Society 95:175-192.

Thacker, C., P. J. Unmack, L. Matsui, and N. Rifenbark. 2007. Comparative phylogeography of five sympatric Hypseleotris species (Teleostei: Eleotridae) in southeastern Australia reveals a complex pattern of drainage basin exchanges with little congruence across species. Journal of Biogeography 34: $1518-1533$. 
Unmack, P. J. 2001. Biogeography of Australian freshwater fishes. Journal of Biogeography 28:1053-1089.

Unmack, P. J. 2013. Biogeography of Australian freshwater fishes. Pages 25-48 in P. Humphries and K. F. Walker (editors). The ecology of Australian freshwater fishes. CSIRO Publishing, Canberra, Australia.

Unmack, P. J., G. R. Allen, and J. B. Johnson. 2013. Phylogeny and biogeography of rainbowfishes (Melanotaeniidae) from Australia and New Guinea. Molecular Phvlogenetics and Evolution 67:15-27.

Unmack, P. J., and T. E. Dowling. 2010. Biogeography of the genus Craterocephalus (Teleostei: Atherinidae) in Australia. Molecular Phylogenetics and Evolution 55:968-984.
Voris, H. K. 2000. Maps of Pleistocene sea levels in South East Asia: shorelines, river systems, time durations. Lournal of Biogeography 27:1153-1167.

Webster, P. J., and N. A. Streten. 1972: Aspects of late Quaternary climate in tropical Australasia. Pages 39-61 in D. Walker (editor). Bridge and barrier: the natural and cultural history of Torres Strait. Research School of Pacific Studies, Australian National University, Canberra, Australia.

Wilson, G. D. F., C. L. Humphrey, D. J. Colgan, K. A. Gray, and R. N. Johnson. 2009. Monsoon-influenced speciation patterns in a species flock of Eophreatoicus Nicholls (Isopoda; Crustacea). Molecular Phvlogenetics and Evolution 51:349364. 